\title{
EXTRACTION, QUANTIFICATION, AND FTIR CHARACTERIZATION OF BARK TANNINS OF FOUR FOREST SPECIES GROWN IN NORTHEAST BRAZIL
}

\author{
Sarah Rebeka Rodrigues Marques ${ }^{2 *} \odot$, Tatiane Kelly Barbosa Azevêdo ${ }^{3} \odot$, Aline Rogéria Freire de

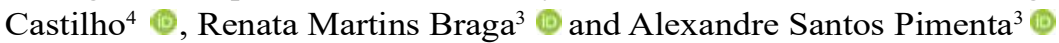

\footnotetext{
${ }^{1}$ Received on 20.06.2021 accepted for publication on 21.09.2021.

${ }^{2}$ Universidade Federal do Rio Grande do Norte, Programa de Pós-Graduação em Ciências Florestais , Macaíba, RN - Brasil. E-mail: <srebekarm@gmail.com>.

3 Universidade Federal do Rio Grande do Norte, Departamento de Engenharia Florestal, Macaíba, RN - Brasil. E-mail: <tatianekellyengenheira@hotmail.com>, <renatabraga.r@gmail.com>and <alexandre.pimenta@ufrn.br>.

${ }^{4}$ Universidade Estadual de Campinas,Departamento de Odontologia, Piracicaba, SP - Brasil. E-mail: <acast@unicamp.br>.

*Corresponding author.
}

\begin{abstract}
Condensed tannins are chemical compounds derived from the secondary metabolism of plants. They are of particular interest due to their broad range of technological uses and applications. The objective of this study was to extract, quantify, and characterize by Fourier-transform infrared spectroscopy (FTIR) the bark tannins of four forest species grown in Northeast Brazil: Acacia mangium, Azadirachta indica, Mimosa tenuiflora, and Mimosa caesalpiniifolia. Bark samples were collected from 5 trees of each species grown in a five-year-old forest stand. Samples were collected, grounded, and submitted to extraction with hot water, then measured to determine total solids content (TSC), Stiasny number (SN), and condensed tannins content (CTC). FTIR spectra were acquired from tannin samples fixed in potassium bromide pellets. Among the four species, M. tenuiflora presented the highest CTC, equal to $23.4 \%$, and the purest crude hot-water extract with SN of 91.27\%. Based on FTIR characterization, tannins from $M$. caesalpiniifolia, A. indica, and $A$. mangium barks were classified as proanthocyanidins and those from $M$. tenuiflora bark as prodelphinidins.
\end{abstract}

Keywords: Forest species bark; Proanthocyanidins; Prodelphinidins

\section{EXTRAÇÃO, QUANTIFICAÇÃO E CARACTERIZAÇÃO POR FTIR DE TANINOS DA CASCA DE QUATRO ESPÉCIES FLORESTAIS CULTIVADAS NO NORDESTE DO $B R A S I L$}

\begin{abstract}
RESUMO - Taninos condensados são compostos oriundos do metabolismo secundário das plantas. Eles são de especial interesse devido à sua ampla gama de aplicações e usos tecnológicos. O objetivo do presente trabalho foi extrair, quantificar e caracterizar por espectroscopia de infravermelho com transformada de Fourier (FTIR) os taninos da casca de quatro espécies cultivadas na região Nordeste do Brazil: Acacia mangium, Azadirachta indica, Mimosa tenuiflora ('jurema preta') e Mimosa caesalpiniifolia ('sabiá' ou 'sansão-do-campo'). Amostras de 5 árvores de cada espécie foram coletadas, moídas e extraídas com água quente, determinando-se os rendimentos de extração. A partir dos extratos foram determinados o teor de sólidos totais (TST), o indice de Stiasny (IS) e o teor de taninos condensados (TTC). Os espectros de FTIR foram adquiridos a partir de amostras de taninos imobilizados em pastilhas de brometo de potássio. Dentre as quatro espécies, M. tenuiflora teve o mais alto TTC igual a 23,4\% e o extrato bruto mais puro com IS de 91,27\%. Com base na caracterização por FTIR, os taninos das cascas de M. caesalpiniifolia, A. indica e A. mangium foram classificados como proantocianidinas e os da casca de M. tenuiflora como prodelfinidinas.
\end{abstract}

Palavras-Chave: Cascas de espécies florestais; Proantocianidinas; Prodelfinidinas.

Silf $(c)$ EY
Revista Árvore 2021;45:e4541 http://dx.doi.org/10.1590/1806-908820210000041 


\section{INTRODUCTION}

The condensed tannins or procyanidins proanthocyanidins and prodelphinidins- are complex compounds containing in their chemical structure flavan-3-ol, galloflavan-3-ol and flavan 3 ol gallate as basic units (Pizzi, 1993; Calegari et al., 2016). Their basic monomers are $(+)$-catechin and $(-)$-epicatechin, typically composed by a resorcinol group (A ring), a catechol group (B ring), and a pyran heterocyclic group (C ring) (Ricci et al., 2015), as presented in Figure 1. The occurrence of condensed tannins is widespread in both gymnosperm and angiosperm tree structures, present in all parts, such as roots, trunk, leaves and fruits. However, in most species, the highest concentrations are found in the tree bark, so it is the part of the tree commonly employed to produce tannins in industrial scale (Paes et al., 2006a).

Since tannins can react with collagen and produce leather, they have been used for centuries in the tanning of animal hides. Because of their ability to react with formaldehyde, tannins are increasingly applied in the production of adhesives for wood bonding. Other large-scale uses of tannins include their employment as flocculants in the treatment of drinking water and organic solvents as ingredients in the pharmaceutical, cosmetic and in food industries (Pizzi, 1993; Carneiro et al., 2010). Tannins can be extracted from tree bark through several methods, and the effectiveness of each technique depends directly on the selectivity of water and solvents (Jahanshaei

$\mathrm{R}^{1}=\mathrm{OH} ; \mathrm{R}^{2}=\mathrm{H}-$ Proanthocyanidins

$\mathrm{R}^{1}=\mathrm{R}^{2}=\mathrm{OH}-$ Prodelphinidins.

$R^{I}=O H ; R^{2}=H-$ Proantocianidinas

$R^{1}=R^{2}=O H-$ Prodelfinidinas.

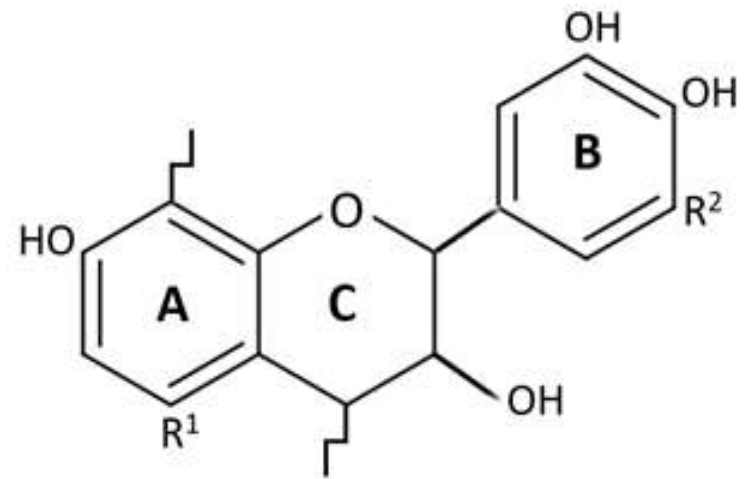

Figure 1 - Structure of a basic condensed-tannin chemical unit.

Figura 1 - Estrutura química da unidade básica de taninos condensados. and Tabarsa, 2012; Sartori et al., 2018; Muhayyidin et al., 2019). According to the same authors, the stability of tannins after extraction only can be guaranteed if a correct method of drying is carried out to avoid biological degradation. Furthermore, the chemical composition of crude extracts is decisively influenced by the method of extraction (Pizzi, 1993) and the drying method to obtain the tannins as a powder (Muhayyidin et al., 2019).

The broad range of applications of tannins in industrial processes requires the ability to characterize these compounds using fast, reliable and, non-destructive methods to permit monitoring of manufacturing routines and to determine their physicalchemical properties. In this context, Fourier-transform infrared spectroscopy (FTIR) is one the instrumental techniques most applied for these purposes due to its low cost, ease of use, reliability and good details of the acquired data compared to other techniques (Ricci et al., 2015; Grasel et al., 2016). The technique consists basically of quantifying the absorption in the mid-infrared region, mainly from 400 to 4,000 $\mathrm{cm}^{-1}$, of molecules containing specific chemical bonds of functional groups, such as $\mathrm{C}=\mathrm{C}, \mathrm{C}-\mathrm{H}, \mathrm{C}=\mathrm{O}$, $\mathrm{C}-\mathrm{O}$, and $\mathrm{OH}$ (Silverstein et al., 2014). FTIR can be applied for the qualitative and quantitative analysis of condensed tannins since it is possible to verify their characteristics as isolated compounds and their use as additives, because structural modifications caused by extraction process or mixing with other matrices can be observed (Ricci et al., 2015).

Brazil's Northeast region has tropical rainy climate in the coastal portion and semiarid in the inland region. For decades, the region has undergone severe deforestation and degradation due to the economic activity and cutting of forests to collect firewood. In recent years, the planting of forests with exotic and native species was increased as an alternative to provide wood for industrial processes and slow deforestation. In this sense, Acacia mangium Willd., Azadirachta indica A. Juss, Mimosa tenuiflora Willd and Mimosa caesalpiniifolia Benth are the main species planted to mitigate deforestation and provide firewood. However, firewood is a low valueadded product, so production of bark tannins is a natural solution to increase incomes of small farmers. Nevertheless, debarking is a costly process and is only feasible if a good yield of tannins can be obtained. If

Revista Árvore 2021;45:e4541 
the yield of tannins is too low, there is no economic justification to collect bark, so only firewood can be marketed. Thus, the knowledge of the tannin content in the bark of the cited species is very important to support decisions on whether or not produce tannins.

Based on the scenario described above, the present study had the goal of extracting, quantifying and characterizing by FTIR the bark tannins from A. mangium, $A$. indica, $M$. tenuiflora, and $M$. caesalpiniifolia cultivated in Northeastern Brazil.

\section{MATERIAL AND METHODS}

\subsection{Bark collection}

The evaluated species were Acacia mangium, Mimosa tenuiflora, Mimosa caesalpiniifolia, and Azadirachta indica, from a five-year-old forest stand located in the municipality of Macaíba, Rio Grande do Norte State, Brazil $\left(05^{\circ} 51^{\prime} 28,8^{\prime \prime} \mathrm{S}\right.$ and $35^{\circ} 21^{\prime} 14,4$ "' $\mathrm{W})$. Local soil is classified as yellow sandy oxisol and the topography is flat relief (Beltrão et al., 1975). The climate is a transition between the types As and BSw, characterized as tropical rainy according to the Köppen classification, with annual average temperature of $27.1^{\circ} \mathrm{C}$ and rainfall from 864 to 1,071 $\mathrm{mm}$.

Five trees of each species were chosen based on criteria of good phytosanitary state. The trees were harvested and debarked and the collected material was stored in plastic bags for further processing and analysis. Samples were used to determine the moisture content. Then the material was placed in a climatecontrolled room at $25{ }^{\circ} \mathrm{C}$ and relative humidity of $65 \%$ for drying until reaching moisture equilibrium, around $12-15 \%$. After 25 days, the bark was ground in a forage crusher equipped with a $2 \mathrm{~mm}$ sieve. For tannin extraction, a proportion (mass/mass) of distilled water and bark equal to 1:10 was employed, respectively. Then, $25 \mathrm{~g}$ of each material was placed in $500 \mathrm{~mL}$ flat-bottomed flasks and submitted to reflux at $120^{\circ} \mathrm{C}$ for 3 hours. The extraction was carried out two times for all five replicates of bark from the sampled trees. For all batches, the extract was filtered to eliminate fine particles. The extracts of each species were put together to form a composite sample and then placed in stainless steel trays, which were left in a solar oven until complete evaporation of water. After that, the powder was ground with a porcelain mortar and pestle and sieved to granulometry of 60 mesh. This material was used for later formulation of the adhesive. Before evaporation, $50 \mathrm{~mL}$ aliquots of the crude extract were retrieved to determine the total solids content (TSC), Stiasny number (SN) and condensed tannins content (CTC), with four replicates for each parameter.

To measure the CTC, the $50 \mathrm{~mL}$ aliquots of the crude extract were oven dried at $60+2{ }^{\circ} \mathrm{C}$ and their total solids content (TSC) was calculated by Equation 1 .

$$
\mathrm{TSC}=((\mathrm{M} 1-\mathrm{M} 2) / \mathrm{M} 1) \times 100
$$

Where:

TSC - total solids content in $50 \mathrm{~mL}$ of crude extract $(\%)$;

$M_{1}$ - initial mass of crude extract $(\mathrm{g})$; (g).

$\mathrm{M}_{2}$ - final mass of solids after water evaporation

To obtain the total condensed tannins content (TTC), first the SN of the extracts was determined by the method described by Guangcheng et al. (1991), with four replications. For this, $4 \mathrm{~mL}$ of formaldehyde $(37 \% \mathrm{~m} / \mathrm{m})$ and $1 \mathrm{~mL}$ of concentrated hydrochloric acid were added to $50 \mathrm{~mL}$ of crude extract. The mixture was kept under reflux for $30 \mathrm{~min}$. After this, the mixture was cooled and filtered and the solids were oven dried at temperature of $60+2{ }^{\circ} \mathrm{C}$ for $48 \mathrm{~h}$. The dried material was weighed and the $\mathrm{SN}$ was calculated by Equation 2. The non-tannins content (NTC) was calculated as the difference between TST and TTC.

$$
\mathrm{SN}=(\mathrm{M} 2 / \mathrm{M} 1) \times 100
$$

Eq. 2

Where:

$$
\begin{aligned}
& \mathrm{SN}=\text { Stiasny number }(\%) \\
& \mathrm{M} 1=\text { mass of solids in } 50 \mathrm{~mL} \text { of crude extract } \\
& \mathrm{M} 2=\text { mass of tannin-formaldehyde precipitate }
\end{aligned}
$$
(g); (g).

With the Stiasny number, the condensed tannins content was calculated by using Equation 3 and expressed as percentage of dry mass of bark.

$\mathrm{CTC}=(\mathrm{TSC} \times \mathrm{SN}) / 100$

Eq.3

Where:

\section{Revista Árvore 2021;45:e4541}

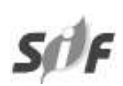


CTC - condensed tannins content $(\%)$;

TSC - total solids content ( $\%)$;

$\mathrm{SN}$ - Stiasny number (\%).

\subsection{Experimental design and statistical analysis}

The experimental design was entirely randomized, with four forest species and assessment of five replicates (4 treatments x 5 replicates). Experimental data were submitted to analysis of variance and when statistical differences were detected, means were compared by the Scott-Knott test at $95 \%$ probability. For statistical analysis, the values of total solids content (TSC), Stiasny number (SN) and condensed tannins content (CTC) were converted to arcsine $[\sqrt{ }(\mathrm{x} / 100)]$, as suggested by Steel and Torrie (1980), to homogenize the variances. Experimental means were compared by the T-test at $95 \%$ probability. All statistical analyses were carried out with the Assistat 7.0 software.

\subsection{FTIR characterization}

Tannin samples were assessed by FTIR. The tannins' spectra were acquired with a Shimadzu IRAffinity-1 spectrometer using $\mathrm{KBr}$ pellets. Before pelletizing, tannin samples were oven-dried at 60 ${ }^{\circ} \mathrm{C}$ for $3 \mathrm{~h}$. A pellet containing only $\mathrm{KBr}$ was used to acquire the reference spectrum. The other pellets were prepared with $\mathrm{KBr}$ and $1 \%(\mathrm{w} / \mathrm{w})$ of the powdered tannin samples. Each spectrum was acquired with 32 scans and resolution of $4 \mathrm{~cm}^{-1}$, from 4,000 to $400 \mathrm{~cm}^{-1}$.

\section{RESULTS}

\subsection{Tannin extraction and quantification}

The results found for total solids content (TSC), Stiasny number (SN) and condensed tannins content (CTC) are presented in the Table 1.

\subsection{FTIR characterization}

In Figure 1, the FTIR spectra acquired for the four forest species A. mangium, M. tenuiflora, $A$. indica and, M. caesalpiniifolia are displayed together for best visualization of their similarity. In Table 2, the spectral attributes are described.

In Figure 2 is presented the individual spectra acquired for each type of bark tannin.

\section{DISCUSSION}

\subsection{Tannin extraction and quantification}

According to Medeiros et al. (2019), TSC refers to the solids able to be extracted from the bark by hot water, but besides the tannins, several other types of compounds may be present. However, a high TSC is not always associated with high tannins content. This depends on the forest species. Among the assessed species, the highest TSC was determined in the bark of $M$. tenuiflora, with value of $27.79 \%$, followed by A. mangium, M. caesalpiniifolia and A. indica with values of $14.80,9.18$ and $7.11 \%$, respectively. The two latter values of TSC were statistically equal. The TSC found in the present study for $M$. tenuiflora is lower than that determined by Medeiros et al. (2018), who observed a value of $44.6 \%$ for the same species. The authors explained such differences in bark solids content by dissimilarities regarding edaphoclimatic conditions and genetic factors.

The SN refers to the flavanol-type tannins that can be precipitated through reaction with formaldehyde, so higher SN means greater purity of the hot-water extract from the bark (Medeiros et al., 2019). For this parameter, the bark extract of $M$. caesalpiniifolia presented the highest value, $91.27 \%$, followed by $\mathrm{M}$. tenuiflora, A. mangium and, A. indica with 83.39, 83.89 and, $73.18 \%$, respectively. A contrast may be pointed out for M. caesalpiniifolia, which even though containing a low concentration of condensed tannins in the bark, had the highest degree of purity for these compounds, with SN value of $91.27 \%$, as cited above.

In turn, CTC directly reflects the real content of condensed tannins existing in the bark of a given

Table 1 - Results of extraction and quantification of tannins from the bark of four forest species grown in Northeast Brazil. Tabela 1 - Resultados da extração e quantificação dos taninos da casca de quatro espécies florestais cultivadas no Nordeste do Brasil.

\begin{tabular}{|c|c|c|c|c|}
\hline$\overline{\text { Species }}$ & $\begin{array}{l}\text { TSC } \\
(\%)\end{array}$ & $\begin{array}{l}\text { SN } \\
(\%)\end{array}$ & $\begin{array}{c}\text { CTC } \\
(\%)\end{array}$ & $\begin{array}{c}\text { NTC } \\
(\%)\end{array}$ \\
\hline$\overline{\text { Mimosa tenuiflora }}$ & $27.79 a$ & $83.39 b$ & $23.40 \mathrm{a}$ & $\overline{4,30 a}$ \\
\hline Mimosa caesalpiniifolia & $9.18 \mathrm{c}$ & $91.27 \mathrm{a}$ & $8.38 \mathrm{c}$ & $0,80 d$ \\
\hline Acacia mangium & $14.80 \mathrm{~b}$ & $83.89 b$ & $12.41 \mathrm{~b}$ & $2,39 b$ \\
\hline Azadirachta indica & $7.11 \mathrm{c}$ & $73.18 \mathrm{c}$ & $5.02 \mathrm{~d}$ & $2,09 \mathrm{c}$ \\
\hline
\end{tabular}

content; NTC - non-tannins components. **Means in columns followed by different letters are statistically dissimilar by the Scott-Knott test at $95 \%$ probability.

TST-teor de sólidos totais; IS - Índice de Stiasny; TTC - teor de taninos condensados. ${ }^{* *}$ Médias nas colunas seguidas por letras distintas são estatisticamente diferentes pelo teste de Scott-Knott a $95 \%$ de probabilidade. 
Table 2 - Attributes of FTIR spectra acquired for bark tannins from Acacia mangium (Am), Mimosa caesalpiniifolia (Mc), Azadirachta indica (Ai), and Mimosa tenuiflora $(\mathrm{Mt})$ trees grown in Northeast Brazil.

Tabela 2 - Caracteristicas do espectro de FTIR dos taninos da casca de árvores de Acacia mangium (Am), Mimosa caesalpiniifolia (Mc), Azadirachta indica (Ai) e Mimosa tenuiflora (Mt) cultivadas no Nordeste do Brasil.

\begin{tabular}{|c|c|c|c|c|}
\hline \multicolumn{4}{|c|}{ Peak $\left(\mathrm{cm}^{-1}\right)$} & \multirow[t]{2}{*}{ Event } \\
\hline$A m$ & $M c$ & Mt & $A i$ & \\
\hline$\overline{3,418}$ & 3,425 & 3,439 & 3,438 & OH stretching vibrations of hydrogen bonds \\
\hline- & 2,925 & - & 2,927 & $\begin{array}{c}\mathrm{C}-\mathrm{H} \text { asymmetrical stretching vibrations of aromatic methoxyl, methyl and lateral-chain } \\
\text { methylene groups }\end{array}$ \\
\hline- & 2,852 & - & 2,799 & $\mathrm{C}-\mathrm{H}$ symmetrical stretching vibrations of aliphatic methylene groups \\
\hline 2,361 & 2,360 & 2,356 & 2,357 & - \\
\hline 2,335 & 2,336 & 2,332 & 2,335 & - \\
\hline 1,604 & 1,605 & 1,605 & 1,607 & $\mathrm{C}=\mathrm{C}$ stretching vibrations of aromatic bond \\
\hline 1,566 & 1,567 & 1,568 & 1,567 & $\mathrm{C}=\mathrm{C}$ stretching vibrations of aromatic bond \\
\hline 1,454 & 1,450 & 1,515 & 1,447 & $\begin{array}{c}\text { Vibrational movement of } \mathrm{C}=\mathrm{C} \text { bonds in the aromatic rings, aromatic } \mathrm{C}-\mathrm{H} \text { bending, } \mathrm{C}-\mathrm{O} \\
\text { stretching and } \mathrm{C}-\mathrm{OH} \text { deformation }\end{array}$ \\
\hline 1,399 & 1,427 & 1,454 & 1,395 & $\begin{aligned} \text { Vibrational movement of } \mathrm{C} & =\mathrm{C} \text { bonds in the aromatic rings, aromatic } \mathrm{C}-\mathrm{H} \text { bending, } \mathrm{C}-\mathrm{O} \\
& \text { stretching and } \mathrm{C}-\mathrm{OH} \text { deformation }\end{aligned}$ \\
\hline- & - & 1,350 & - & $\mathrm{C}=\mathrm{C}$ stretching vibrations \\
\hline 1,337 & 1,410 & 1,332 & 1,280 & Region of $\mathrm{C}-\mathrm{H}$ bond deformation \\
\hline 1,194 & 1,275 & 1,240 & 1,203 & $\mathrm{C}-\mathrm{O}$ extension in the pyran ring of tannins \\
\hline 1,156 & 1,248 & 1,153 & 1,143 & $\mathrm{C}-\mathrm{O}$ extension in the pyran ring of tannins and $\mathrm{C}-\mathrm{OH}$ stretching vibrations \\
\hline 793 & 826 & 793 & 806 & Deformation of C-H from aromatic rings out-of-plane vibrations \\
\hline
\end{tabular}

forest species, but it can vary depending on the method employed for its determination. Once again, the highest value was determined for M. tenuiflora, content close to that of black wattle (Acacia mearnsii), the most important source of tannins in Brazilian forests. The high CTC determined for the M. tenuiflora bark indicates the species as a potential source of condensed tannins on a large scale, with the possibility of expanding production of this non-wood product in places where the tree can be cultivated. However, care must be taken at the time of bark collection since, as found by Azevêdo et al. (2017), the tannins content can vary as a function of the phenophase of the tree, being higher at the end of the rainy season when the plant has a greater number of green leaves. In the present work, the bark collection was carried out at the end of the rainy season and the value of CTC $(23.40 \%)$ determined here is close to that found by the cited authors, of $21.90 \%$. For the other forest species, the CTC had values of $12.41,8.38$ and $5.02 \%$ for $A$. mangium, M. caesalpiniifolia and $A$. indica, respectively. For the M. caesalpiniifolia bark, for instance, the value determined in this work for the condensed tannins content is in accordance with that of $8.38 \%$ observed by Azevêdo et al. (2017). This similarity may be related to the equal age of the trees ( 5 years) and also to the equal measurement methods.

\subsection{FTIR characterization}

According to Kassim et al. (2011), the shape of the $\mathrm{OH}$-stretching band provides preliminary information on the occurrence of a polymerization process. Condensed tannins exhibit a varying degree of polymerization, which results in a broad range that goes from 3,700 to $3,000 \mathrm{~cm}^{-1}$ in the spectrum. In the present assessment, bands referring to stretching vibration of $\mathrm{OH}$ groups from phenolic structures were identified at 3,418;3,429; 3,452 and $3,418 \mathrm{~cm}^{-1}$ for A. mangium, $M$. tenuiflora, $A$. indica and, $M$. caesalpiniifolia. This typical broad range observed in the spectrum is a consequence of the confluence of the substituent $\mathrm{OH}$ bands in different positions in molecules with distinct polymerization degrees and also from multiple interactions of the tannin molecules with a specific substrate (Bulut et al., 2009).

The $\mathrm{C}-\mathrm{H}$ bond stretching is located in the region from 3,100 to $3,000 \mathrm{~cm}^{-1}$, and can extend to values near $2,800 \mathrm{~cm}^{-1}$. In this study, minor peaks were observed between 2,915 and $2,852 \mathrm{~cm}^{-1}$ for $M$. tenuiflora and from 2,928 and 2,799 $\mathrm{cm}^{-1}$ for $A$. indica. Most likely, for both types of tannins the bands represented minor peaks since the occurrence of the interactions and the degree of polymerization did not significantly affect the vibrational frequencies of the molecular structures, 


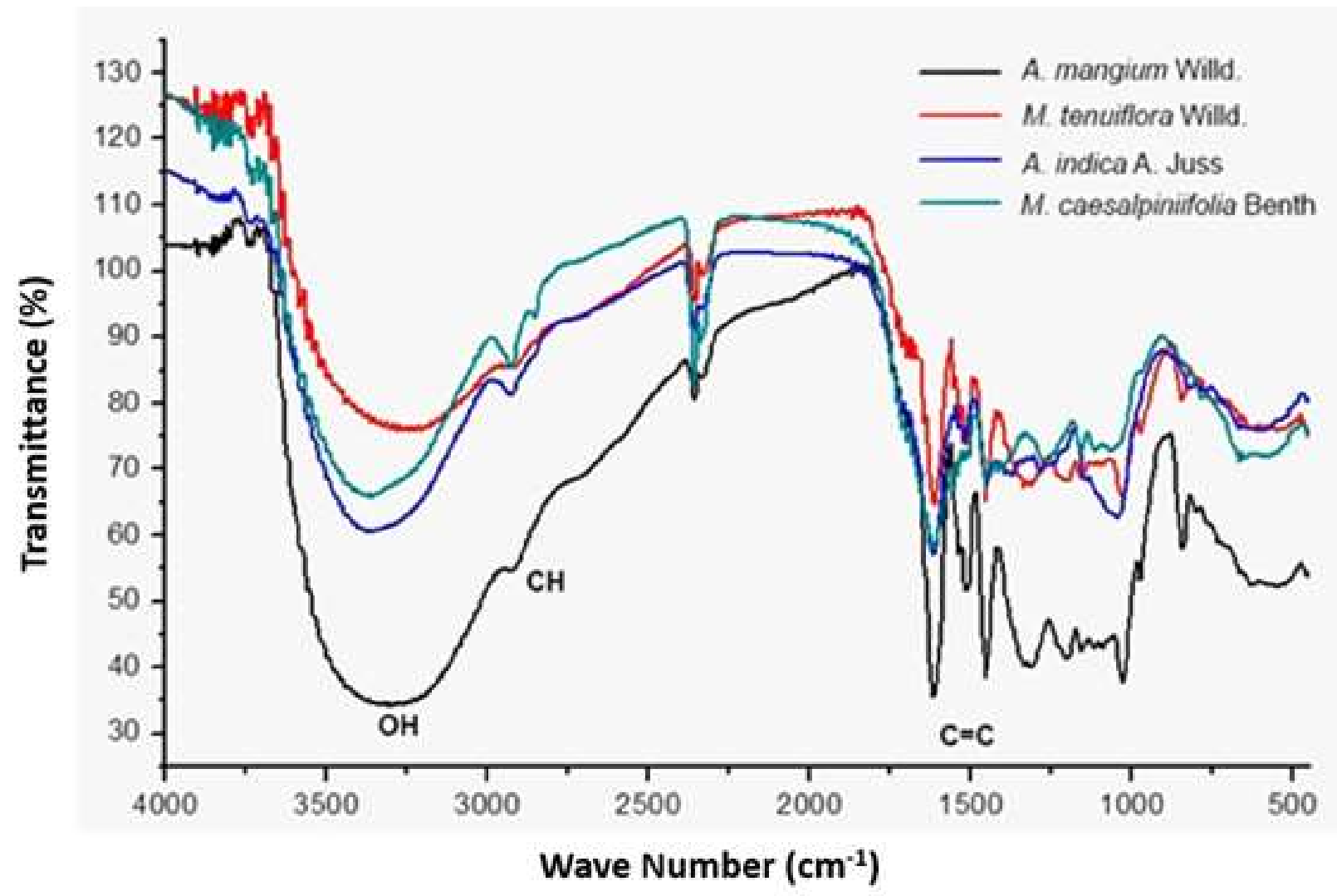

Figure 2 - FTIR spectra of bark tannins from A. mangium, M. tenuiflora, A. indica and M. caesalpiniifolia trees grown in Northeast Brazil. Figura 2 - Espectros de FTIR da casca de árvores de A. mangium, M. tenuiflora, A. indica and M. caesalpiniifolia cultivados no Nordeste do Brasil.

and the position and intensities of the bands were not highly modified, as also reported by Cocciardi et al. (2005), Soto et al. (2005), Jahanshaei and Tabarsa (2012), Chupin et al. (2013) and Faris et al. (2016). According to Ricci et al. (2015), in FTIR spectra of condensed tannins, the stretching related to aliphatic groups is diagnostical because it can give information on the methylation in the chemical structure of these compounds. This type of stretching appears in the spectra as narrow peaks in the region around 2,970 and 2,929 $\mathrm{cm}^{-1}$ for methyl groups and around 2,920 and $2,780 \mathrm{~cm}^{-1}$ for methylene substituents, which was observed in the present work.

As defined by Socrates (2004), the spectral region between 1,620 and $1,400 \mathrm{~cm}^{-1}$ is related mainly to vibrational movements of $\mathrm{C}=\mathrm{C}$ bonds in the aromatic rings, with several weak and strong characteristic peaks. In the spectra from condensed tannins, a double absorption or a strong shoulder- shaped band may occur between 1,620 and 1,604 $\mathrm{cm}^{-1}$, associated with these types of vibrational movements (Ricci et al. 2015). In both spectra of the $M$. caesalpiniifolia and $M$. tenuiflora tannins, these events appeared as peaks located at 1,605; 1,607 and, 1,604 $\mathrm{cm}^{-1}$, respectively (Figure 2 and 3). For all tannins assessed in this work, $\mathrm{C}=\mathrm{C}$ aromatic stretching was observed also in the spectral regions from 1,580 and $1,615 \mathrm{~cm}^{-1}$ and 1,450 and 1,510 $\mathrm{cm}^{-1}$. The behavior of these bonds in FTIR spectra is not significantly affected by structural modifications due to the presence of distinct substituents and degrees of polymerization (Fernández; Agostin, 2007). The $M$. caesalpiniifolia tannins presented the most intense $\mathrm{C}=\mathrm{C}$ peaks. This information combined with the highest Stiasny number determined here for the hotwater extracts from this species reflects the high purity of such extracts. The high Stiasny number combined with strong $\mathrm{C}=\mathrm{C}$ peaks was indicated by Ntenga et al.

Revista Árvore 2021;45:e4541 

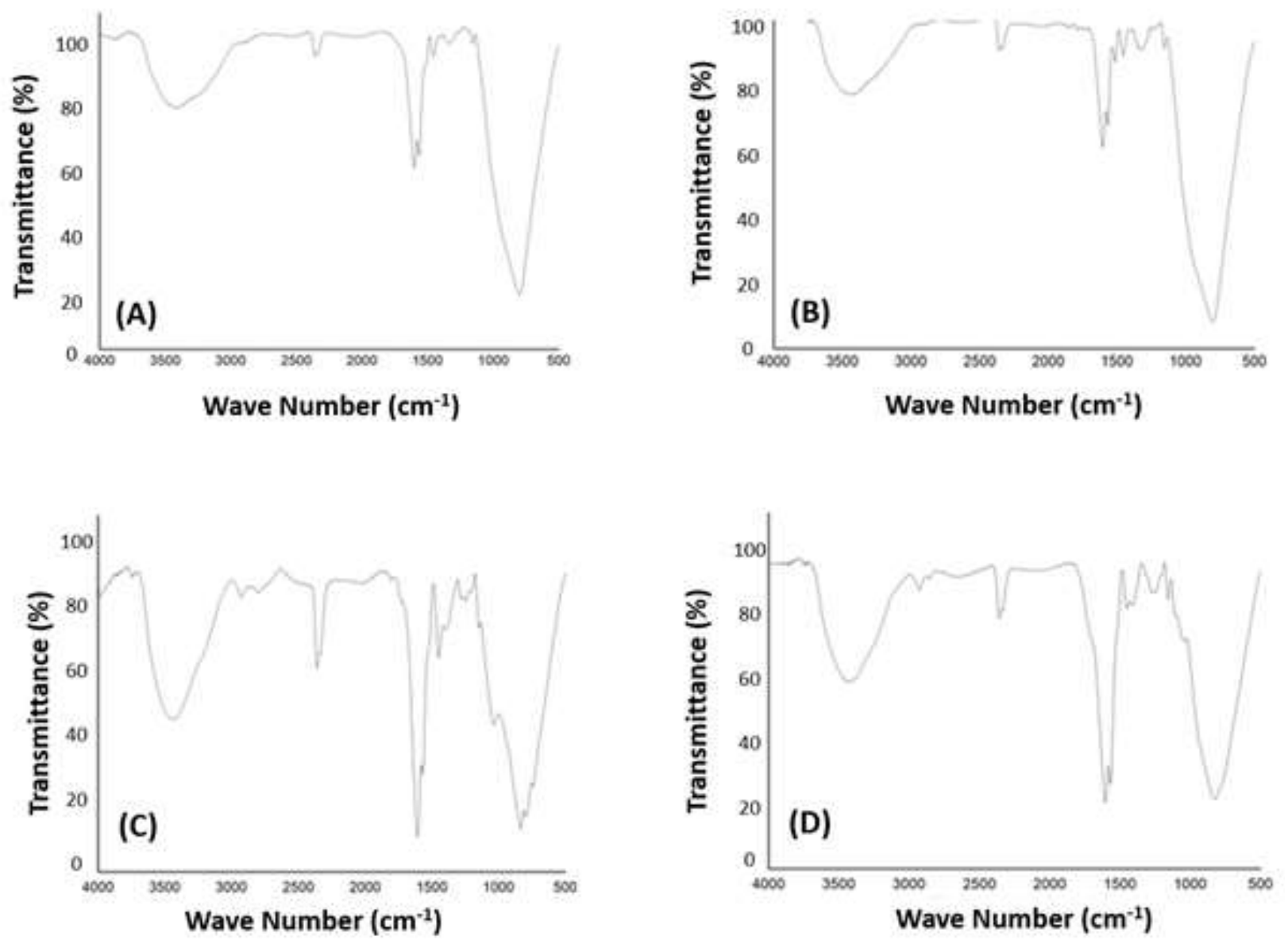

Figure 3 - Single FTIR spectra of bark tannins from A. mangium (A), M. tenuiflora (B), A. indica (C) and M. caesalpiniifolia (D) trees grown in Northeast Brazil.

Figura 3 - Espectros de FTIR dos taninos da casca de A. mangium (A), M. tenuiflora (B), A. indica and M. caesalpiniifolia.

(2017) as an indicator of purity of hot-water tannin extracts.

The peaks observed at $1,567 \mathrm{~cm}^{-1}$ for $M$. caesalpiniifolia and A. indica, $1,468 \mathrm{~cm}^{-1}$ for $M$. tenuiflora and $1,566 \mathrm{~cm}^{-1}$ for $A$. mangium confirm the stretching vibration of $\mathrm{C}=\mathrm{C}$ aromatic ring bonds present in condensed tannins (Ntenga et al., 2017; Sartori et al., 2018). The peaks located at 1,450 $\mathrm{cm}^{-1}$ (M. caesalpiniifolia), $1,447 \mathrm{~cm}^{-1}$ (A. indica) and $1,454 \mathrm{~cm}^{-1}$ (A. mangium) particularly result from the combination of aromatic bending of $\mathrm{C}-\mathrm{H}$, stretching of $\mathrm{C}-\mathrm{O}$ and deformation of $\mathrm{C}-\mathrm{OH}$ (Konai et al. 2017). The band at $1,450 \mathrm{~cm}^{-1}$ observed in the spectrum of $M$. caesalpiniifolia may be related to the asymmetric bending of $\mathrm{CH}_{3}$ from protein material released along with the tannins during the hot-water extraction process (Kumar et al. 2012). Other authors have attributed bands from 1,451 to 1,370 and 1,340 $\mathrm{cm}^{-1}$ to vibrational deformations of methylene and methyl groups (Baddi et al., 2004; Easton et al., 2009). They reasoned that the simultaneous presence of clear stretching in the spectral region of 2,970 and $2,870 \mathrm{~cm}^{-1}$ and the occurrence of bands associated with specific bending movements observed from 1,460 to 1,380 and $1,330 \mathrm{~cm}^{-1}$, usually denominated umbrella deformation, constitute strong evidence of the presence of methylated structures in condensed tannins. 
The peaks located at 1,332 and $1,337 \mathrm{~cm}^{-1}$ for $M$. tenuiflora and A. mangium (Figure 2), respectively, can be attributed to flat bending vibration, as also described by Ping et al. (2012). The peak at 1,280 $\mathrm{cm}^{-1}$ in the $A$. indica spectrum corresponds to the $\mathrm{C}-\mathrm{O}$ of the pyran ring of flavan-3-ol-based tannins. In turn, the peak at $1,240 \mathrm{~cm}^{-1}$ observed in the spectrum of $M$. tenuiflora tannins represents the stretching of the $\mathrm{C}=\mathrm{O}$ group from carboxyl groups, which may indicate the presence of residues of gallic acid (Konai et al. 2017). The region between 1,350 and $1,100 \mathrm{~cm}^{-1}$ is related to the stretching vibrations of $\mathrm{C}-\mathrm{O}$, and between 1,300 and $1,200 \mathrm{~cm}^{-1}$ to the vibrations of the tannin $\mathrm{B}$ ring, while the range from 1,200 to $1,100 \mathrm{~cm}^{-1}$ contains vibrations of the A ring (Tondi; Petutschnigg, 2015). Further according to Socrates (2004) and Konai et al. (2017), the peaks occurring between 1,275 and $1,246 \mathrm{~cm}^{-1}$ are attributed to the presence of catechin and proanthocyanidins. They can be clearly observed in the spectra of tannins from $M$. caesalpiniifolia, A. indica $(1,203$ to $1,143 \mathrm{~cm}-1)$ and $A$. mangium $(1,194$ to $\left.1,156 \mathrm{~cm}^{-1}\right)$. Finally, peaks located in the region from 900 to $740 \mathrm{~cm}^{-1}$ are attributed to movements of $\mathrm{OH}$ from aromatic alcohols and out-of-plane bending of aromatic C-H (Socrates 2004). Considering as diagnostical the peaks (Figure 2) located between 1,275 and $1,248 \mathrm{~cm}^{-1}$, the tannins from M. caesalpiniifolia, $A$. indica and, $A$. mangium barks belong to the class of proanthocyanidins and due to the larger peak situated around $1,350 \mathrm{~cm}^{-1}$, the tannins from $M$. tenuiflora bark can be classified as prodelphinidins type.

Based on the tannin yields of the bark from the forest species evaluated, $M$. tenuiflora and $A$. mangium seem to be viable as possible sources of commercial tannins, especially the first species, for which the condensed tannins content reached a mean value of $23.40 \%$.

\section{CONCLUSIONS}

The bark of $M$. tenuiflora presented good potential as source of tannins on commercial scale due to its high yield. Although M. caesalpiniifolia bark had low yield of extractable tannins, they had the highest degree of purity, which indicates the possibility of directing them to end uses where this quality is desirable, such as the pharmaceutical industry. Tannins from $M$. caesalpiniifolia, $A$. indica and, $A$. mangium barks are proanthocyanidins and those from $M$. tenuiflora bark are prodelphinidins.

\section{AUTHOR CONTRIBUTIONS}

T.K.B. Azevedo conceptualized and supervised the experiment, supervised the statistical analysis of the experimental data; S.R.R. Marques was in charge of the experiment organization, data collection, statistical analysis, and wrote the initial draft of the manuscript, A.R.F. de Castilho and R.M. Braga assisted the data collection; and A.S. Pimenta revised the statistical analysis, finalized the manuscript and translated it from Portuguese to English. An American native speaker proofread the finalized manuscript. All authors approved the final version of the manuscript.

\section{REFERENCES}

Azevêdo TKB, Paes JB, Calegari L, Santana GM. Teor de taninos condensados presente na casca de jurema-preta (Mimosa tenuiflora) em função das fenofases. Floresta e Ambiente. 2017;24. doi:10.1590/2179-8087.026613

Baddi GA, Albuquerque JA, González J, Cegarra J, Hafidi M. Chemical and spectroscopic analyses of organic matter transformations during composting of olive mill wastes. International Biodeterioration \& Biodegradation. 2004;54(1):39-44.

Beltrão VA, Freire LCM, Santos MF. Levantamento semi-detalhado da área do Colégio Agrícola de Jundiaí - Macaíba/RN, 1975. Recife: SUDENE Recursos de Solos, Divisão de Reprodução, 380 p.

Bulut E, Ozacar M. Rapid, facile synthesis of silver nanostructure using hydrolyzable tannins. Industrial \& Engineering Chemistry Research. 2009;48(12):5686-5690.

Calegari L, Lopes PJG, Oliveira E, Gatto DA, Stangerlin DM. Quantificação de taninos nas cascas de jurema-preta e acácia-negra. Pesquisa Florestal Brasileira. 2016;36(85):61-69.

Carneiro ACO, Vital BR, Carvalho AM, Oliveira AC, Pereira BL, Andrade BGD. Determinação da massa molar de taninos vegetais através da técnica da cromatografia de permeação em gel. Scientia Forestalis. 2010;38:419-429.

Chupin L, Motillon C, Bouhtoury FC, Pizzi A, Charrier B. Characterisation of maritime pine (Pinus pinaster) bark tannins extracted under different conditions by spectroscopic methods, FTIR and HPLC. Industrial 
Crops and Products. 2013;49:897-903.

Cocciardi RA, Ismail AA, Sedman J. (2005). Investigation of the potential utility of single-bounce attenuated total reflectance Fourier transform infrared spectroscopy in the analysis of distilled liquors and wines. Journal of Agricultural and Food Chemistry. 2005;53(8):2803-2809.

Easton CD, Jacob MV, Shanks RA, Bowden BF. Surface and chemical characterization of PolyLA thin films fabricated using plasma polymerization. Chemical Vapor Deposition. 2009;15(7-9):179-185.

Faris AH, Ibrahim MNM, Rahim AA. Preparation and characterization of green adhesives using modified tannin and hyperbranched poly (amineester). International Journal of Adhesion and Adhesives. 2016;71:39-47. doi: 10.1016/j. ijadhadh.2016.08.009

Fernández K, Agostin E. Quantitative analysis of red wine tannins using Fourier-transform midinfrared spectrometry. Journal of Agricultural Food Chemistry. 2007;55:7294-7300.

Grasel FS, Ferrão MM, Wolf CR. Development of methodology for identification the of the polyphenolic by FTIR associated with multivariate analysis. Spectrochimica Acta Part A: Molecular and Biomolecular Spectroscopy. 2016;153:94-101.

Guangcheng Z, Yunlu L, Yazaki Y. Extractives yields, Stiasny values and polyflavanoid contents in barks from six Acacia species in Australia. Australian Forestry. 1991;54(3):154-156.

Jahanshaei S, Tabarsa T. Eco-friendly tannin-phenol formaldehyde resin for producing wood composites. Pigment \& Resin Technology. 2012;41(5):296-301.

Kassim MJ, Hussin MH, Achmad A, Dahon NH, Suan TK, Hamdan HS. Determination of total phenol, condensed tannin and flavonoid contents and antioxidant activity of Uncaria gambir extracts. Indonesian Journal of Pharmacy. 2011;22(1):50-59.

Konai N, Raidandi D, Pizzi A, Meva'a L. Characterization of Ficus sycomorus tannin using ATR-FT MIR, MALDI-TOF MS and ${ }^{13} \mathrm{C}$ NMR methods. European Journal of Wood Products. 2017;75:807-815. doi: 10.1007/s00107-017-1177-8

Kumar P, Selvi SS, Prabha AL, Kumar KP,
Ganeshkumar RS, Govindaraju M. Synthesis of silver nanoparticles from Sargassum tenerrimum and screening phytochemicals for its antibacterial activity. Nano Biomedicine and Engineering. 2012;4(1):12-16.

Medeiros JX, Calegari L, Silva GH, Oliveira E, Pimenta AS. Measurement of tannic substances in forest species. Floresta e Ambiente 2018;25(3):1-8.

Medeiros JX, Calegari L, Silva GH, Tanajura JA, Braz RL. Bark and fruit Extracts Anadenanthera colubrina (Vell.), Mimosa tenuiflora (Willd.) and Acacia mearnsii (Wild.) Species. Journal of Experimental Agriculture. 2019;30(1):1-7. doi: $10.9734 / \mathrm{JEAI} / 2019 / 46500$

Muhayyidin AHM, Bakar NFA, Ghazali NA, Sauki A, Ibrahim WA. Characterization of powdered Rhizophora mucronate bark tannins extractives using different drying methods. International Journal of Engineering and Advanced Technology. 2019;9(1).

Ntenga R, Pagore FD, Pizzi A, Mfoumou E, Ohandja LMA. Characterization of tannin-Based resins from the barks of Ficus platyphylla and of Vitellaria paradoxa: composites' performances and applications. Materials Sciences and Applications. 2017;8(12):899.

Paes JB, Diniz CEF, Marinho IV, Lima CR. Avaliação do potencial tanífero de seis espécies florestais de ocorrência no Semiárido brasileiro. Cerne. 2006a; 12:232-238.

Ping L, Pizzi A, Guo ZD, Brosse N. Condensed tannins from grape pomace: characterization by FTIR and MALDI TOF and production of environment friendly wood adhesive. Industrial Crops and Products. 2012;40:13-20.

Pizzi A. Tannin-Based adhesives. In: Pizzi A. (Ed.). Wood adhesives: chemistry and technology. New York: Marcel Dekker, 1993.

Ricci A, Olejar KJ, Parpinello GP, Kilmartin PA, Versari A. Application of Fourier Transform Infrared (FTIR) Spectroscopy in the characterization of tannins. Applied Spectroscopy Reviews. 2015;50(5):407-442. doi: 10.1080/05704928.2014.1000461

Sartori CJ, Mota GS, Miranda I, Mori FA, Pereira $\mathrm{H}$. Tannin extraction and characterization of polar 
extracts from the barks of two Eucalyptus urophylla hybrids. BioResources. 2018;13(3):4820-4831.

Silverstein, R. M., Webster, F. X., Kiemle, D. J., Bryce, D. L. Spectrometric identification of organic compounds. John Wiley and Sons, New York, NY, USA, 2014, 8th Edition, pp 95-137.

Soto R, Freer J, Baeza J. Evidence of chemical reactions between di-and poly-glycidyl ether resins and tannins isolated from Pinus radiata $\mathrm{D}$. Don bark. Bioresource Technology. 2005;96(1):95-101.
Socrates G. Infrared and Raman characteristic group frequencies: tables and charts / George Socrates. $3^{\text {rd }}$ Edition, John Wiley \& Sons: Chichester, NY, USA, 2004, ISBN 0470093072

Steel RGD, Torrie JH. Principles and procedures of statistics, a biometrical approach (No. Ed. 2). McGraw-Hill Kogakusha Ltd, 1980.

Tondi G, Petutschnigg A. Middle infrared (ATR FTMIR) characterization of industrial tannin extracts. Industrial Crops and Products. 2015;65:422-428. 